\title{
The Effect of K-Carrageenan Addition to the Characteristics of Jicama Starch-Based Edible Coating and Its Potential Application on The Grapevine
}

\author{
Sri Budi Wahjuningsih ${ }^{\# 1}$, Rohadi ${ }^{\# 2}$, Siti Susanti ${ }^{*}$, Henricus Yayan Setyanto ${ }^{+}$ \\ ${ }^{\#}$ Department of Agricultural Product Processing, Faculty of Agricultural Technology, Semarang University, Semarang, Indonesia \\ Email: ${ }^{1}$ sribudiwahjuningsih@yahoo.com; ${ }^{2}$ rohadijarod_ftp@usm.ac.id \\ *Food Technology Division, Department of Animal Science and Agriculture, Diponegoro University, Semarang, Indonesia \\ Email: sitisusanti5678@gmail.com \\ ${ }^{+}$Small Business Actor of Contento Snack, Semarang, Indonesia \\ Email: henricusyayan@gmail.com
}

\begin{abstract}
Public awareness of food quality is an essential thing during the packaging application. Considering the environment issue, edible coating with starch-based has been applied as packaging with environment-friendly. The high quality of starch is also produced by jicama (Pachyrhizus erosus). However, the application of jicama as an edible coating for grapevine (Vitis vinira L) remains unknown. Therefore, this research aims to determine the influence of k-carrageenan addition with various concentration to the physical and chemical characteristics of Jicama (Pachyrhizus erosus) starch-based edible coating and its potential application on Grapevines (Vitis vinira $L$.). This research was using randomized design with one addition factor (k-carrageenan): A1 =k-carrageenan $0.5 \%(w / v) ; A 2=k$-carrageenan 1\% (w/v); A3 =k-carrageenan 1.5\% (w/v); A4 =k-carrageenan 2\% (w/v); A5 =k-carrageenan $2 \%$ $w / v)$. All measurements are repeated three times. The collected data were analyzed by variance analysis $(p<0.05)$ and Duncan's differential analysis for further analysis. The result showed that k-carrageenan addition was significantly influenced the thickness, moisture content, tensile strength value, and WVTR value of the produced edible coating $(\mathbf{p}<0.05)$. Treatment A5 has produced films with the good physical characteristics consisting of moisture content at $22.76 \%$, thickness at $1.01 \mathrm{~mm}$, tensile strength at $7.42 \mathrm{kgf} / \mathrm{cm} 2$, and WVTR value at $6.748 \mathrm{~g} / \mathrm{m} 2$ per hour. The edible coating applied on Grapevine with the dipping technique showed that $\mathrm{k}$ carrageenan was significantly increasing the rate of vitamin $C$ and reducing the weight up to day 9 of storage $(p<0.05)$ as compared to control. Meanwhile, based on the sensory evaluation, k-carrageenan addition has insignificantly influenced the color and the texture preference $(\mathbf{p}>\mathbf{0 . 0 5})$.
\end{abstract}

Keywords - edible coating; grapevine (Vitis vinira L.); jicama (Pachyrhizus erosus); k-carrageenan.

\section{INTRODUCTION}

One of the impacts of the globalization era and population growth is the increase in food demands. This condition is also supported by the improvement of public awareness toward the importance of food quality. Food security as a manifestation of food quality is an important thing to be paid attention, one of which is the packaging application that is easily degraded and does not endanger to the health. For several decades, synthetic packaging such as plastic has been commonly used with the result that caused problems for health and the environment [1], [2]. Packaging technology that is safe and does not damage the environment is very necessary, for example, edible coating [3].
The existence of edible coating application allowed the food packaging can be eaten beside the main function as a coating to inhibit the occurrence of food damage due to the loosing of moisture, oxygen, carbon dioxide, aroma and lipids [4]. During this period, starch which is a polysaccharide has been commonly used as an edible coating because of its ability to reduce the loss of moisture from the food [5]. Because it is biodegradable, starch-based coatings have potency as the plastic polymers replacer [6].

It has been known that beside cassava, the high-quality starch can also be produced from other species of tuber namely jicama. Its scientific name called Pachyrhizus erosus [7]. Previous research reported that the combination of jicama starch with chitosan as an edible coating possessed a good effect on the characteristics of Nile tilapia fish [8]. In 
that case, chitosan was used as a stabilizer for a suspension. In addition to chitosan, carrageenan is also often used as a stabilizer because it's a hydrophilic characteristic which can increase the continuous phase viscosity so that the emulsion finally stabilizes [9]. Until recent time, the application of jicama starch as an edible coating on fruit, especially grapevine (Vitis vinifera $L$ ) has not been done widely. As we know, grapevine is a very perishable fruit with high moisture level so that it is susceptible to evaporation processes which can reduce the quality [10]. Therefore, the application of the edible coating on the grapevine is clearly can play an important role in maintaining its quality.

The current investigation was conducted to get more insight into the effect of carrageenan as the stabilizing agent to the characteristic of jicama starch-based edible coating. Furthermore, the purpose of this study knew of edible coating potency made from a combination of jicama starchcarrageenan was evaluated about its application on the grapevine. The information resulted from this investigation was expected can increase the commodity value of jicama in the field of agroindustry as well as its contribution to the advance of postharvest technology in horticulture commodity.

\section{MATERIAL AND METHOD}

\section{A. Material}

The raw material used in this research consists of jicama (Pachyrhizus erosus), Grapevine (Vitis vinifera L), and kcarrageenan. Reagents used to consist of standard iodine solution (Merck, German) and starch soluble (Merck, German).

\section{B. Research Procedure}

1) Extraction of jicama starch: the extraction process was according to Hasbullah (2000) [11] with modification. It was started by peeling and washing jicama. The peeled jicama crushed and added with water (1:1) to produce jicama slurry. The jicama slurry was filtered for paste liquid. Then, it was precipitated for 24 hours and dried at $50^{\circ} \mathrm{C}$ for 8 hours. Furthermore, it crushed and sieved (80 mesh).

2) Edible film making: Starch was diluted by aquadest with $4 \%$ concentration $(\mathrm{b} / \mathrm{v})$ using magnetic stirrer and heated on hot plate stirrer at $60-70^{\circ} \mathrm{C}$ for 20 minutes. Carrageenan was added at various concentrations (b/v) i.e. $0.5 \%$ (A1); $1.0 \%$ (A2); $1.5 \%$ (A3); $2.0 \%$ (A4); and $2.5 \%$ (A5) of the total volume in aquadest. Then, the mixture was stirred by using magnetic stirrer and heated on the hot plate up to $80^{\circ} \mathrm{C}$. The carrageenan solution homogenized with the starch solution. Furthermore, glycerol $1 \%$ added to the solution at $70-80^{\circ} \mathrm{C}$. The edible coating solution poured into the $20 \times 10 \mathrm{~cm}$ glass plate. The, it dried using the oven at $60^{\circ} \mathrm{C}$ for 5-6 hours.

3) The coating on grapes: The coating process is performed by dipping the fruit into coating liquid. The dipped fruit is then hung and air dried on wire gauze until no drop from the coating. And observation is then performed for 3 days, 6 days, and 9 days at room temperature.

\section{Analysis}

1) Parameters analysis: The moisture level was analyzed based on the AOAC (1995) [12]. The crushed material sample weighed for $1-2 \mathrm{~g}$ in a weighing bottle, then dried in an oven at $1000 \mathrm{C}-1500 \mathrm{C}$ for 35 hours depending on the material. After that, put in into exicator and measure the weight. Those treatments were repeated until a constant weight was reached (difference in consecutive weighing is less than $0.2 \mathrm{mg}$ ). Weight reduction demonstrated the water content within the material. Coating thickness measured by using micrometer screw gauge (accuracy $0.001 \mathrm{~mm}$ ). Coating sample inserted between the cylinder spindle and the anvil of micrometer screw gauge. Then, the rated thickness value read by the tool. Tensile strength measured using Llyod Instrument. The tested material cut into the specific shape (under tool specification) and size. The start button pushed twice. The first push would activate the tool and the second push would operate the tool (test in operation). The tensile strength calculated by dividing the maximum force to the coating until it was torn (Newton) by the coating's cross-sectional area $(\mathrm{m} 2)$. Water vapor transmission rate (WVTR) determined gravimetrically by modifying the method proposed by Xu et al., (2005) [13]. The film sample contained $20 \mathrm{~g}$ silica gel, and placed in a container with $\mathrm{NaCl}$ solution $40 \%(\mathrm{~b} / \mathrm{v})(\mathrm{RH}=75 \%)$ at $25 \mathrm{oC}$. The cup has an inner diameter of $75 \mathrm{~mm}$ and a height of 30 $\mathrm{mm}$. The water vapor diffused through the film which absorbed by the silica gel and increased additional weight. The cup's weight recorded for 8 hours. A linear regression equation made for the data obtained to determine its slope. The water vapor transmission rate determined by dividing the slope of the cup's weight increment by film's external surface. Weight loss was calculated according to Gardjito (2003) [15]. The deviation of initial weight and final weight (weight during observation) was divided by initial weight resulted in a weight loss of fruit. Vitamin $\mathrm{C}$ was calculated by spectrophotometry method. About 200-300 grams of sample was crushed by using blender until it became slurry. Weigh 10-20 grams of slurry and put it into $100 \mathrm{ml}$ measuring flask and added by aquadest. Centrifugation conducted to separate the filtrate or filter it using Gooch crucible to separate the filtrates. Then, filtrates about 5-25 $\mathrm{ml}$ inserted into $125 \mathrm{ml}$ Erlenmeyer flask. Add $2 \mathrm{ml}$ starch solution $1 \%$ and titrates it using $0.01 \mathrm{~N}$ iodine standard solution. Determine the amount of standard iodine and ascorbic acid within the material. $1 \mathrm{ml} 0.01 \mathrm{~N}$ iodine $=0.88$ mg ascorbic acid.

2) Sensory analysis: The sensory test used is the scoring test by utilizing 20 semi-trained panelists. This test conducted based sensory characteristics such as color, aroma, and texture. The obtained score addressed for statistical analysis to examine the difference. Each coated grape sample was compared based on color and texture with 1 to 5 score. The lowest score demonstrated bad physical characteristics while the highest score showed good physical characteristics.

3) Statistical analysis: The data analyzed by using variance test. Duncan Multiple Range Test (DMRT) at significance level 5\% was conducted for further analysis. The parameters such as water content, thickness, tensile 
strength, and water vapor transmission rate were applied for observation. Moreover, water content, weight loss, vitamin c, and sensory test subjected as further parameters.

\section{RESULT AND DISCUSSION}

This section presents results and discussion in three main points. It describes the results on edible film water content, water vapor transmission rate, and Grape's water content. The details of this section is presented as follows:

\section{A. Edible Film Water Content}

The edible coating's water is content with carrageenan addition with range of $22.76 \%-27.1 \%$. This result is lower than the edible film using chitosan material as a lactic acid solvent $2 \%$ with water content $27.34 \%-32.48 \%$. Based on variance test results, carrageenan's concentration has noticeable influence $(\mathrm{p}>0.05)$ on the coating's water content as presented in Table 1 below.

TABLE I

THE PHYSICAL AND MECHANICAL CHARACTERISTICS OF CARRAGEENAN

\begin{tabular}{|c|c|c|c|c|}
\hline Treatments & Water content $(\%)$ & Thickness $(\mathbf{m m})$ & Tensile strength $\left(\mathbf{k g f} / \mathbf{c m}^{2}\right)$ & WVTR $\left(\mathbf{g} / \mathbf{m}^{2} / \mathbf{h o u r}\right)$ \\
\hline $\mathrm{A}_{1}$ & $27.10 \pm 1.60^{\mathrm{b}}$ & $0.54 \pm 0.03^{\mathrm{a}}$ & $0.54 \pm 0.24^{\mathrm{a}}$ & Undetected $^{\mathrm{a}}$ \\
\hline $\mathrm{A}_{2}$ & $24.20 \pm 2.27^{\mathrm{ab}}$ & $0.56 \pm 0.03^{\mathrm{a}}$ & $2.40 \pm 1.52^{\mathrm{b}}$ & $9.60 \pm 0.52^{\mathrm{c}}$ \\
\hline $\mathrm{A}_{3}$ & $23.50 \pm 0.99^{\mathrm{ab}}$ & $0.58 \pm 0.61^{\mathrm{a}}$ & $3.27 \pm 0.84^{\mathrm{b}}$ & $3.20 \pm 1.65^{\mathrm{a}}$ \\
\hline $\mathrm{A}_{4}$ & $24.11 \pm 2.67^{\mathrm{ab}}$ & $0.65 \pm 0.10^{\mathrm{a}}$ & $6.24 \pm 0.60^{\mathrm{c}}$ & $7.26 \pm 1.50^{\mathrm{b}}$ \\
\hline $\mathrm{A}_{5}$ & $22.76 \pm 0.76^{\mathrm{a}}$ & $1.01 \pm 0.19^{\mathrm{b}}$ & $7.42 \pm 0.90^{\mathrm{c}}$ & $6.75 \pm 0.99^{\mathrm{b}}$ \\
\hline
\end{tabular}

Table 1 exhibited that there is a difference between A1 treatment with carrageenan's concentration of $0.5 \%$ and A5 treatment with carrageenan's concentration of $2.5 \%$. Carrageenan's hydrophilic characteristic induced the binding to the more water which will be evaporated after oven processing. The higher amount of carrageenan on coating will reduce the water content during heating. It makes the coating's texture more rigid than the coating with carrageenan's. The higher the water content on the coating will make the coating vulnerable to fungal growth, which leads to the coating's reduced quality.

1) Thickness: Based on variance test results, the difference in carrageenan's concentration has noticeable influence $(p>0.05)$ on the coating's thickness. Table 1 demonstrated that there is an increase in thickness in the A1 to A5 treatments. The most significant difference is on the A5 treatment which demonstrated the highest carrageenan's concentration than the other treatments (carrageenan 2.5\%). The thickness of the edible coating is influenced by molding area, coating solution volume, and carrageenan's concentration. This is in line with the results of research conducted by Handito (2011). It exhibited that a higher concentration of carrageenan starch causes the increase of edible coating's thickness. Furthermore, it would increase the total dissolved solids existing in the coating forming solution. Thus a thicker film will be produced after the drying process. According to Bourtoom (2007), the coating sheet is formed while the oven process is in progress [6]. Water is evaporated, and the particles are wrinkling to form coating sheet. In brief, the coating forming process starts with reduced space between binding particles in a liquid. Thus a coating sheet will be formed after the evaporation process.

2) Tensile strength: The strength of coating tensile value within range from $0.539 \mathrm{kgf} / \mathrm{cm} 2$ (A1) to $7.423 \mathrm{kgf} / \mathrm{cm} 2$ (A5). The variance test results show that there is noticeable difference ( $\mathrm{p}>0.05)$ among coatings A1 (carrageenan 0.5\%), A2 (carrageenan 1\%), A3 (carrageenan 1.5\%), A4 (carrageenan 2\%) and A5 (carrageenan 2.5\%). The tensile strength values of treatments A1, A2, and A3 are lower than A4 and A5 treatments. The additional concentration of Carrageenan on coating will increase the tensile strength value of edible coating. It assured by the ability of carrageenan to form strong polymer matrix and generated stronger intermolecular tensile strength. This may be viewed on the increasing tensile strength value from A1 to A2 and $\mathrm{A} 3$, then to A4 and A5. The A4 and A5 treatments have the highest tensile strength values than the other treatments about $6.240 \mathrm{kgf} / \mathrm{cm} 2$ and $7.423 \mathrm{kgf} / \mathrm{cm} 2$. The concentration of carrageenan influences the increasing tensile strength value. It exhibited a similar result to the research conducted by Ariska (2015) [15]. The tensile strength value was increased by utilizing coat derived from the core of the banana plant with carrageenan. The higher concentration of carrageenan added into the edible coating to generate a stronger coating matrix. Therefore, it will need a higher force to break the edible coating.

\section{B. Water Vapor Transmission Rate (WVTR)}

The WVTR value of coating ranges from 3.198 to 9.603 $\mathrm{g} / \mathrm{m} 2 /$ hour. This value is relatively low compared to the results of research conducted by Breemer (2012) [16], in which sweet potato based edible coating with CMC addition has WTVR value ranging from $7.07 \mathrm{~g} / \mathrm{m} 2 /$ hour to 12.34 $\mathrm{g} / \mathrm{m} 2 /$ hour. Based on variance test results, the concentration of carrageenan noticeably influences the WVTR value of coating. However, there is no WVTR value obtained from A1 treatment which is allegedly caused by low concentration and low thickness of carrageenan. It makes the compactness of coating is not as good as the other treatments. Moreover, the A3 treatment has WVTR value about $3.198 \mathrm{~g} / \mathrm{m} 2 /$ hour, which noticeably different from A4 treatment which is 7.256 $\mathrm{g} / \mathrm{m} 2 /$ hour. Then, the A 2 treatment is $9.603 \mathrm{~g} / \mathrm{m} 2 /$ hour which different from A3 treatment and A5 with $6.748 \mathrm{~g} / \mathrm{m} 2 /$ hour. The hydrophilic characteristic of carrageenan causes those differences.

According to Handito (2011), more quantity of carrageenan with hydrophilic characteristic in the film matrix increased the film area which may be used to transfer the water vapor [17]. Therefore, the water vapor transmission rate will become higher. Carrageenan is one material within edible coating which classified as hydrocolloid with bad resistance to water vapor. The 
hydrophilic characteristic of Carrageenan causes the edible coating to absorb water vapor [6] easily.

\section{Grape's Water Content}

According to Table 2, it showed that on day 3, the water content decreased less than $3 \%$ for all treatments. However, on day 6 , it is noticeable that in the $\mathrm{K}$ treatment, the uncoated grape has the highest decrease at $6.45 \%$. In the A1 to A5 treatments, there is a small amount of water content decreased as compared to the $\mathrm{K}$ treatment. Based on the variance test results, it exhibited that there is a difference $(\mathrm{p}>0.05)$ in the $\mathrm{K}$ treatment (carrageenan 0\%) and A5 treatment (carrageenan 2.5\%). The A5 treatment is stated as the best since it may inhibit water content for $2.46 \%$.

TABLE II

WATER CONTENT OF GRAPE WITH ADDED CONCENTRATION OF CARRAGEENAN

\begin{tabular}{|c|c|c|c|c|}
\hline Treatment & M1 (\%) & M2 (\%) & M3 (\%) & M4 (\%) \\
\hline K & $83.99+0.88 \mathrm{a}$ & $80.44+0.40 \mathrm{a}$ & $77.54+2.14 \mathrm{a}$ & $73.47+0.90 \mathrm{a}$ \\
\hline A1 & $83.74+2.57 \mathrm{a}$ & $81.09+3.25 \mathrm{a}$ & $79.02+0.80 \mathrm{ab}$ & $78.30+1.39 \mathrm{~b}$ \\
\hline A2 & $82.87+1.91 \mathrm{a}$ & $80.50+0.68 \mathrm{a}$ & $79.30+1.10 \mathrm{ab}$ & $78.58+0.47 \mathrm{~b}$ \\
\hline A3 & $83.19+1.28 \mathrm{a}$ & $81.69+2.03 \mathrm{a}$ & $80.27+1.26 \mathrm{ab}$ & $78.12+1.72 \mathrm{~b}$ \\
\hline A4 & $84.60+1.04 \mathrm{a}$ & $82.55+3.48 \mathrm{a}$ & $80.38+2.72 \mathrm{ab}$ & $79.04+1.27 \mathrm{~b}$ \\
\hline
\end{tabular}

$\mathrm{K}$ was $0 \%$ of carrageenan's concentration while A1, 2, 3, 4 , and 5 were concentration of carrageenan i.e. $0.5 ; 1.0 ; 1.5$; 2.0 ; and $2.5 \%(\mathrm{~b} / \mathrm{v})$ respectively. M1-4 was moisture level on day $0,3,6$, and 9 , respectively. Data were presented as mean \pm STDEV of 3 repetitions samples $(n=3)$. Different superscripts in the same column showed significant different $(\mathrm{p}>0.05)$

On day 9, treatments A1, A2, A3, A4, and A5 may inhibit water content decrease less than $4 \%$ except in $\mathrm{K}$ treatment which decreased up to $10 \%$. Based on variance test results, there is a more noticeable difference in $\mathrm{K}$ treatment (carrageenan 0\%) with A5 treatment (carrageenan 2.5\%), but there is no difference in all treatments with carrageenan addition (A1, A2, A3, A4, and A5).

$\mathrm{A} 1,2,3,4$, and 5 were concentration of carrageenan i.e. 0.5 ; $1.0 ; 1.5 ; 2.0$; and $2.5 \%(\mathrm{~b} / \mathrm{v})$ respectively. Data were presented as mean \pm STDEV of three repetitions samples $(n=3)$. Different superscripts in the same column showed significant different $(\mathrm{p}>0.05)$

1) Grape's weight loss: Grape may experience weight loss along with a longer duration of storage at room temperature. The results of grape's weight loss during storage are given in Table 2. Fig. 1 shows the grape structural without carrageenan and carrageenan added $0,5 \%$ and $2,5 \%$.
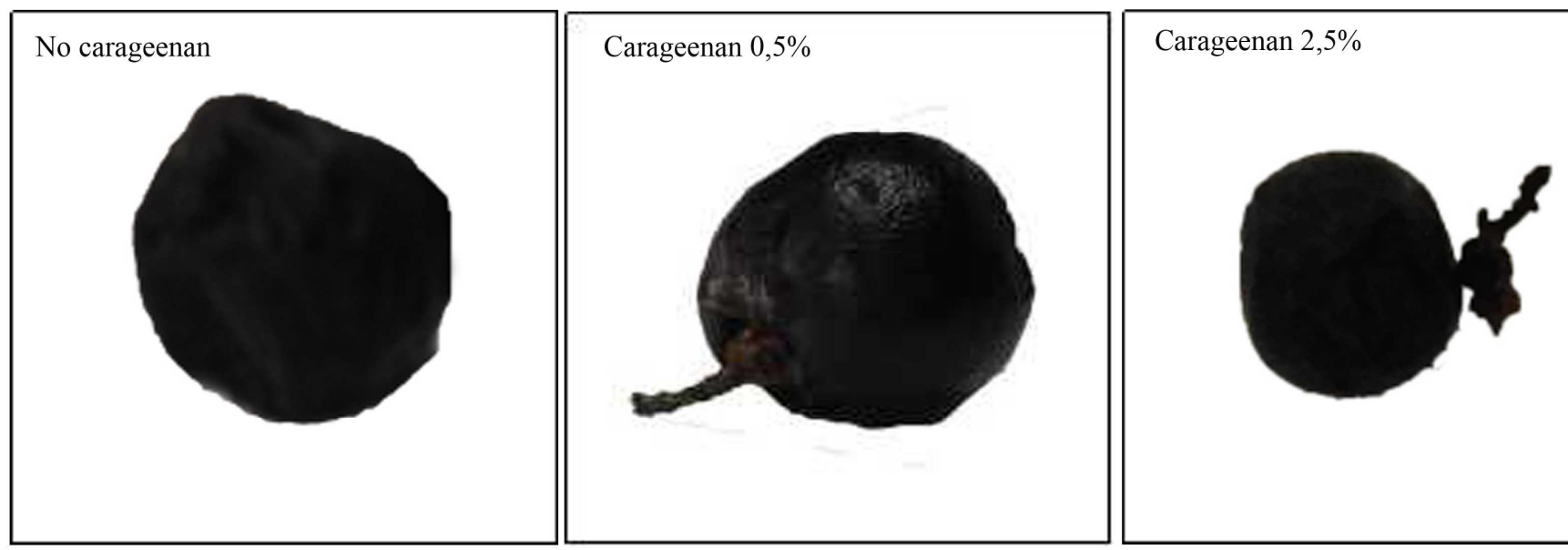

Fig.1 Jicama Starch-Based Edible Coating without k-carrageenan, k-carrageenan $0.5 \%$ and k-carrageenan $2.5 \%$ to weight losses of grape. The higher concentration of Carrageenan predicted increased the thickness of the coating. Thus, it can cover the space of water molecule which will evaporate from the grape.

On day 3 in Table, 3 showed the weight loss value of grape coated with carrageenan ranges from $2.94 \%$ to $4.24 \%$, and the value in $\mathrm{K}$ treatment is $12.58 \%$. According to ANOVA test results, there is no noticeable difference ( $>0.05)$ in the weight loss of treatments A1, A2, A3, A4 and A5 during storage. The noticeable difference $(p>0.05)$ occurs in the $\mathrm{K}$ treatment, in which uncoated fruit experiences relatively significant to the weight loss at $32.17 \%$ on day nine as compared to coated fruit. On day 6 and day 9, the A1 and A5 treatment experienced weight loss differently. In brief, A1 treatment has a weight loss of about $10.64 \%$ and $21.35 \%$ while A5 treatment has $7.98 \%$ and $14.73 \%$ of weight loss. 
TABLE III

WEIGHT LOSS OF GRAPE WITH AN ADDED CONCENTRATION OF CARRAGEENAN

\begin{tabular}{|c|c|c|c|}
\hline Treatment & $\mathbf{W}_{\mathbf{1}}(\boldsymbol{\%})$ & $\mathbf{W}_{\mathbf{2}}(\boldsymbol{\%})$ & $\mathbf{W}_{\mathbf{3}}(\boldsymbol{\%})$ \\
\hline K & $12.58 \pm 1.37^{\mathrm{b}}$ & $24.36 \pm 4.06^{\mathrm{b}}$ & $32.17 \pm 7.57^{\mathrm{b}}$ \\
\hline A1 & $3.431 \pm 0.19^{\mathrm{a}}$ & $10.64 \pm 0.89^{\mathrm{a}}$ & $21.35 \pm 1.55^{\mathrm{a}}$ \\
\hline A2 & $4.243 \pm 1.30^{\mathrm{a}}$ & $11.72 \pm 2.88^{\mathrm{a}}$ & $20.56 \pm 4.52^{\mathrm{a}}$ \\
\hline A3 & $3.427 \pm 0.83^{\mathrm{a}}$ & $9.39 \pm 1.48^{\mathrm{a}}$ & $15.90 \pm 2.85^{\mathrm{a}}$ \\
\hline A4 & $3.739 \pm 1.18^{\mathrm{a}}$ & $7.72 \pm 2.08^{\mathrm{a}}$ & $14.99 \pm 1.44^{\mathrm{a}}$ \\
\hline A5 & $2.941 \pm 1.37^{\mathrm{a}}$ & $7.983 \pm 1.67^{\mathrm{a}}$ & $14.73 \pm 1.04^{\mathrm{a}}$ \\
\hline
\end{tabular}

$\mathrm{K}$ was $0 \%$ of carrageenan's concentration while A1, 2, 3, 4 , and 5 were concentration of carrageenan i.e. $0.5 ; 1.0 ; 1.5$; 2.0 ; and $2.5 \%(\mathrm{~b} / \mathrm{v})$ respectively. W1-4 was weight loss on day $0,3,6$, and 9, respectively. Data were presented as mean \pm STDEV of 3 repetitions samples $(n=3)$. Different superscripts in the same column showed significant different $(\mathrm{p}>0.05)$

Weight loss of fruit is caused by respiration activity. Respiration process continues after the harvesting process of fruit. Within the respiration process, oxygen is absorbed to be used in the oxidation process to produce energy, then followed by emission of oxidation remnants in the form of $\mathrm{CO} 2$ and water [18].
The weight loss level was getting lower as the concentration of carrageenan increased within each treatment. Inhibition of respiration process is better by increasing the thickness and compactness of coating's molecule binding. The weight loss decreases because of carrageenan's concentration is also found in the research conducted by [19].

2) Vitamin $C$ content of grape: Generally, fruit experiences oxidation process within the storage. This process is decreasing the vitamin c content of grape. Vitamin $\mathrm{C}$ is easily oxidized to L-dehydroascorbic acid, and it tends to experience a further change to L-diketogulonic [20]. The results of vitamin $\mathrm{c}$ test during storage are presented in Table 4.

TABLE IV

THE VITAMIN C CONTENT OF GRAPE WITH AN ADDED CONCENTRATION OF CARRAGEENAN

\begin{tabular}{|c|c|c|c|c|}
\hline Treatment & $\begin{array}{c}\text { Vitamin C } \\
\text { on day 0 (mg) }\end{array}$ & $\begin{array}{c}\text { Vitamin C } \\
\text { on day 3 (mg) }\end{array}$ & $\begin{array}{c}\text { Vitamin C } \\
\text { on day 6 (mg) }\end{array}$ & $\begin{array}{c}\text { Vitamin C } \\
\text { on day 9 (mg) }\end{array}$ \\
\hline K & $4.12 \pm 0.28^{\mathrm{a}}$ & $3.94 \pm 0.16^{\mathrm{a}}$ & $3.02 \pm 0.28^{\mathrm{a}}$ & $1.38 \pm 0.28^{\mathrm{a}}$ \\
\hline A1 & $4.12 \pm 0.28^{\mathrm{a}}$ & $3.94 \pm 0.16^{\mathrm{a}}$ & $3.39 \pm 0.16^{\mathrm{b}}$ & $2.84 \pm 0.16^{\mathrm{b}}$ \\
\hline A2 & $4.22 \pm 0.32^{\mathrm{a}}$ & $3.94 \pm 0.16^{\mathrm{a}}$ & $3.67 \pm 0.16^{\mathrm{bc}}$ & $3.48 \pm 0.16^{\mathrm{c}}$ \\
\hline A3 & $4.22 \pm 0.32^{\mathrm{a}}$ & $4.03 \pm 0.32^{\mathrm{a}}$ & $3.48 \pm 0.16^{\mathrm{bc}}$ & $3.58 \pm 0.28^{\mathrm{c}}$ \\
\hline A4 & $4.31 \pm 0.16^{\mathrm{a}}$ & $3.94 \pm 0.16^{\mathrm{a}}$ & $3.67 \pm 0.16^{\mathrm{bc}}$ & $3.58 \pm 0.28^{\mathrm{c}}$ \\
\hline A5 & $4.03 \pm 0.32^{\mathrm{a}}$ & $4.03 \pm 0.16^{\mathrm{a}}$ & $3.76 \pm 0.16^{\mathrm{c}}$ & $3.67 \pm 0.16^{\mathrm{c}}$ \\
\hline
\end{tabular}

$\mathrm{K}$ was $0 \%$ of carrageenan's concentration while $\mathrm{A}_{1,2,3,4 \text {, and } 5}$ were concentration of carrageenan i.e. $0.5 ; 1.0 ; 1.5 ; 2.0$; and $2.5 \%(\mathrm{~b} / \mathrm{v})$, respectively. Data were presented as mean \pm STDEV of 3 repetitions samples $(n=3)$. Different superscripts in the same column showed significant different $(\mathrm{p}>0.05)$

The vitamin c content on day 0 and day 3 is within range $4.033 \mathrm{mg} / 100 \mathrm{~g}$ to $4.308 \mathrm{mg} / 100 \mathrm{~g}$ and $3.942 \mathrm{mg} / 100 \mathrm{~g}$ to $4.033 \mathrm{mg} / 100 \mathrm{~g}$, respectively. Based on the variance test results, the concentration of carrageenan does not noticeably influence $(p>0.05)$ vitamin $c$ content on day 0 and day 3 . The difference $(p>0.05)$ has seen on day 6 in $K$ treatment (carrageenan 0\%), A1 treatment (carrageenan 0.5\%), and A5 treatment (carrageenan 2.5\%). High concentration of carrageenan in the A5 treatment generates strong coating sheet to inhibit the oxidation process at room temperature.

The similar result is found on day 9, the concentration of carrageenan significantly influencing all treatments. The A1 treatment has the least vitamin c content as compared to the other coatings with $2.842 \mathrm{mg} / 100 \mathrm{~g}$ grape. While A2, A3, A4 and A5 treatments may maintain the vitamin c content up to $\geq 3.483 \mathrm{mg} / 100 \mathrm{~g}$ grape.
3) The sensory characteristic of grape: The evaluation of fruit quality involves the sense of taste of compounds which influence the aroma, flavor, and crispiness of fruit. By determining the quality of those critical components, then it must be combined with the panel's subjective evaluation to provide meaningful information on fruit's quality [21], [22]. The results of the grape's sensory test during storage are given in Table 5.

TABLE V

THE SENSORY VALUE OF GRAPE WITH AN ADDED CONCENTRATION OF CARRAGEENAN

\begin{tabular}{|c|c|c|c|}
\hline Treatment & Color & Texture & Aroma \\
\hline A1 & $3.24^{\mathrm{a}}$ & $2.71^{\mathrm{a}}$ & $2.62^{\mathrm{a}}$ \\
\hline A2 & $3.19^{\mathrm{a}}$ & $3.19^{\mathrm{a}}$ & $2.57^{\mathrm{a}}$ \\
\hline A3 & $3.29^{\mathrm{a}}$ & $3.00^{\mathrm{a}}$ & $2.86^{\mathrm{ab}}$ \\
\hline A4 & $2.67^{\mathrm{a}}$ & $2.86^{\mathrm{a}}$ & $3.24^{\mathrm{ab}}$ \\
\hline A5 & $2.62^{\mathrm{a}}$ & $3.10^{\mathrm{a}}$ & $3.71^{\mathrm{b}}$ \\
\hline
\end{tabular}

Explanation: A1: carrageenan's concentration 0.5\%, A2: carrageenan's concentration 1\%, A3: carrageenan's concentration $1.5 \%$, A4: carrageenan's concentration $2 \%$, A5: carrageenan's concentration $2.5 \%$. The values are the 
average of 21 repetitions. Different superscripts in the same column showed a noticeable difference $(p>0.05)$. Based on variance test results, there is no difference $(p>0.05)$ color and texture parameters within each treatment. The grape's sensory test is conducted on day 9 using a scoring test.

The color tests of treatments A1, A2, and A3 have an average value higher than $\mathrm{A} 4$, and $\mathrm{A} 5$ treatment since the coating's color of fruit within $\mathrm{A} 1, \mathrm{~A} 2$, and $\mathrm{A} 3$ treatment is clear. Although there is no difference within each treatment, the concentration of carrageenan within coating influences its color. Grapes with A4 and A5 treatment have a clear yellow color which tends to be white because of the relatively thick coating.

In the grape's surface texture test, there is no skin wrinkling within each treatment. The reduction of weight loss and water content will make the texture of fruit turn into wrinkled. The texture test value of each treatment is not significantly different since the external layer of fruits within all treatments is sturdy texture According to the ANOVA test results, there is a difference $(p>0.05)$ in the aroma value of A1, A2, and A5 treatments. The A1 and A2 treatment has low values of grape's aroma such as 2.62 and 2.57, respectively. Meanwhile, the A5 treatment is the highest value of grape's aroma about 3.71 since the sour aroma of grape in A5 treatment is not strong compared to the other treatments.

\section{CONCLUSION}

This study concludes that the k-carrageenan $2.5 \%$ may become the best-selected treatment for grape edible coating application with increasing vitamin $\mathrm{C}$ rate and lowest weight lost level. However, based on the sensory treatment, kcarrageenan as the best treatment as the grape coating has a pure color, soft texture, and no acidic color.

\section{REFERENCES}

[1] C.Z Yang, S.I Yaniger, V.C. Jordan, D.J Klein, and G.D. Bittne, Most Plastic Products Release Estrogenic Chemicals: A Potential Health Problem That Can Be Solved. Environ Health Perspect. 119 (7): 989-996. 2011.

[2] B.S. MuthuLi, Y, J.Y. Hu, and P.Y. MokAn Exploratory Comparative Study on Eco-Impact of Paper and Plastic Bags. Journal of Fiber Bioengineering and Informatics. 1 (4): 307-320. 2009

[3] JH. Han. Innovations in food packaging. Elsevier, Academic Press, USA. 2014
[4] S. Galus and J. Kadzinska. Food applications of emulsion-based edible films and coatings. Trends in Food Science \& Technology, 45(2): 273-283. 2015.

[5] B. Hassan, SAS. Catha, AI. Hussain, K.M. Zia. N. Akhtar. Recent advances on polysaccharides, lipids and protein-based edible films and coatings: A review. International Journal of Biological Macromolecules 109:1095-1107. 2018

[6] T. Bourtoom. Edible Film and Coatings; Characteristics and Properties, Int. Food Res. J. 15 (3), 1-12. 2008

[7] L.B.G Lemus, GC, Dominguez, MPS Cruz, MD Ramirez, MR Miranda, JJC, Perez. Ultrasound-assisted extraction of starch from frozen jicama (P. erosus) roots: Effect on yield, structural characteristics and thermal properties. CyTA-Journal of Food 16 (1): 738-746. 2018.

[8] D. Li, Y. Zhao, P. Han, C. Yang, X. Liang, L. Li and S. Cai. Effect of chitosan-Jicama starch coating on changes in qualities of fresh Nile tilapia (Oreochromis niloticus) fillets during ice storage. Food Science + Technology 53 (9): 2220-2228. 2018

[9] J.C. Cheng and O.G. Jones Stabilizing zein nanoparticle dispersions with l-carrageenan. Food Hydrocolloids 69: 28-35. 2017.

[10] W.I. Bi, C. Pan, XY, Hao, ZH, MM., Cui Kher Markovic Z., Wang QC., Da Silva JAT. Cryopreservation of grapevine (Vitis spp.)—a review. In Vitro Cellular \& Developmental Biology-Plant 53 (5): 449-460. 2017.

[11] Hasbullah. Teknologi Tepat Guna dan Agroindustri Kecil Sumatera Barat. Sumatera Barat: Dewan Ilmu Pengetahuan, Teknologidan Industri. 2000.

[12] AOAC. Official Methods of Analysis of the Association of Official Analytical Chemists. AOAC Inc., Washington. 1995.

[13] Y.X. Xu, K.M. Kim, M.A. Hanna, and D. Nag. Chitosan-starch composite film: preparation and characterization. Industrial Crops and Products 21: 185- 192. 2005

[14] Gardjito, Murdijati dan Agung Setya Wardana. Hortikultura, Teknik Analisis Pasca Panen. Transmedia Global Wacana. Yogyakarta. 2003.

[15] R. Ariska, and Suyatno. Pengaruh Konsentrasi Karagenan Terhadap Sifat Fisik dan Mekanik Edible Film dari Pati Bonggol Pisang dan Karagenan dengan Plasticizer Gliserol. Universitas Negeri Surabaya. Surabaya. 2015.

[16] R. Breemer, J. Polnaya, Febby., dan J. Pattipeilohy. sifat mekanik dan laju transmisi uap air edible film pati ubi jalar. Universitas Pattimura. Ambon. 2012.

[17] Handito, D. 2011. Pengaruh Konsentrasi Karagenan Terhadap Sifat Fisik dan. Mekanik Edible Film. Jurnal Agroteksos 21 (2-3): 151-157

[18] Dwiari, Sri R. Teknologi Hasil Pangan. Pusat Pembukuan, Departemen Pendidikan Nasional. Jakarta. 2008.

[19] Huse, M. Anugerah., Wignyanto, dan I. A.Dewi. Aplikasi Edible Coating dari Karagenan dan Gliserol untuk Mengurangi Penurunan Kerusakan Apel Romebeauty. Universitas Brawijaya. Malang. 2014.

[20] F. G. Winarno. Kimia Pangan dan Gizi. Gramedia Pustaka Utama. Jakarta. 1997.

[21] B. B. Santoso and B. S. PurwokoFisiologi dan Teknologi Pasca Panen Tanaman Hortikultura. Indonesia Australia Eastern University Project. 187 hal. 1995.

[22] B. Santoso, S. Daniel, dan P. Rindit. Kajian Teknologi Edible Coating Dari Pati dan Aplikasinya untuk Pengemasan Primer Lepok Durian. Jurnal teknologi dan Industri Pangan. Vol XV (3). 2004 